Research Article

\title{
Understanding the CSR Awareness of Large Construction Enterprises in China
}

\author{
Linlin Xie $\mathbb{D}^{1},{ }^{1}$ Ting Xu $\mathbb{D}^{1},{ }^{1}$ Yun Le, ${ }^{2}$ Qing Chen, ${ }^{3}$ Bo Xia $\mathbb{D}^{3},{ }^{3,4}$ and Martin Skitmore ${ }^{3}$ \\ ${ }^{1}$ School of Civil Engineering and Transportation, South China University of Technology, Guangzhou 510641, China \\ ${ }^{2}$ School of Economics and Management, Tongji University, Shanghai 200092, China \\ ${ }^{3}$ School of Civil Engineering and Built Environment, Queensland University of Technology, Brisbane 4001, Australia \\ ${ }^{4}$ College of Civil Engineering, Hefei University of Technology, Hefei 230009, China
}

Correspondence should be addressed to Ting Xu; 201821008640@mail.scut.edu.cn

Received 8 June 2020; Revised 8 November 2020; Accepted 10 November 2020; Published 26 November 2020

Academic Editor: Dong Zhao

Copyright (C 2020 Linlin Xie et al. This is an open access article distributed under the Creative Commons Attribution License, which permits unrestricted use, distribution, and reproduction in any medium, provided the original work is properly cited.

\begin{abstract}
With the rapid growth of the construction industry in China in recent years, its impact on society and the environment is increasing, as well as the importance of corporate social responsibility (CSR). In order to understand the CSR awareness and CSR practices of Chinese domestic construction enterprises, this study conducted a comprehensive content analysis of the CSR reports of China's leading 100 domestic construction enterprises. The results show that the Chinese construction industry's CSR awareness is generally poor and CRS practices mainly involve corporate governance, environmental management, occupational health and development, economic responsibility, community development, and overseas responsibility. State-owned enterprises are more concerned with community responsibility, while private enterprises pay more attention to economic and employee development. These findings not only reveal the CSR awareness and CSR practices of Chinese domestic construction enterprises but also provide practical implications for construction enterprises in other countries to integrate CSR into their corporate governance system and strengthen their CSR practices.
\end{abstract}

\section{Introduction}

As a pillar industry in most countries, the construction industry is a great driving force for national economic development. It plays a significant role in promoting the development of urbanization and new rural construction and driving employment levels $[1,2]$, providing nearly $7 \%$ of jobs worldwide [3]. According to the National Bureau of Statistics of China [4], the construction industry provides nearly 30 million jobs and contributes 7\% of GDP. Meanwhile, the construction industry consumes a large amount of building materials and emits a large amount of carbon dioxide during production activities [5], being the world's second largest carbon emitter accounting for approximately $33 \%$ of global carbon emissions [6]. In China, the construction industry consumes a substantial amount of energy, which accounts for nearly $30 \%$ of the total Chinese annual national energy supply [7]. Construction industry activities lead to many problems such as disturbing biodiversity, generating greenhouse gases and carbon emissions, producing waste materials $[8,9]$, and causing health and safety related incidents [10] - accounting for $30-40 \%$ of casualties globally [3].

Therefore, the construction industry needs to take responsibility for the impact of its activities on the outside world in pursuit of its own interests $[11,12]$. To achieve this, construction enterprises need to accept corporate social responsibility (CSR), which is defined as a voluntary initiative carried out by an entity to express its ethical contributions to enhancing the quality of life of its employees and the community $[13,14]$. This requires the company to do the right thing; be a good citizen [15]; build a sound reputation among employees, unions, suppliers, and community representatives; and provide accountable and transparent CSR reporting. Given the impact of construction activities on society, construction companies need to be 
cognizant of the need to fulfill the requirements of CSR and contribute to the implementation of sustainable construction [16-19].

Although it has also been found that companies engaging in CSR are able to boost their image and increase their profit margins to an above-average level $[18,20]$, construction industries in developing countries including China have not fully embraced CSR. Comparing the CSR reports of international construction companies in Europe, the United States/Canada, and Asia/China, Liao et al. [21] conclude that Chinese construction enterprises have a relatively poor awareness of social responsibility. This is a particular issue for contractors in China because of the increasingly important roles they play in the international construction market [22].

Previous research into the CSR awareness and practices of Chinese construction enterprises mainly focus on large international contractors $[23,24]$, with little attention paid to domestic construction enterprises. Given the country's rapid development of the construction industry and the increasing importance of construction enterprises to the national economy, environment, and society, it is important to appreciate how domestic construction enterprises understand and implement CSR practices, such as the aspects of CSR on which they focus, and the existing CSR practices that need to be improved. However, none of these issues has yet been adequately addressed to date in the current body of knowledge.

Therefore, this article aims to reveal the CSR awareness of domestic construction enterprises and improve the implementation of CSR practices. A content analysis of CSR reports of Chinese construction enterprises is conducted for research purpose because a CSR report serves as a primary channel for companies to disclose the implementation of corporate social responsibility. However, the release of CSR reports is not mandatory in China, and normally only largeand medium-scale enterprises publish them-a fact confirmed in our preliminary research. Therefore, this paper focuses on large construction enterprises from the list of the top 500 Chinese construction enterprises in 2016 [25].

The distinguishing feature of this study from previous studies is that we focus on domestic construction enterprises to understand their CSR awareness and their implementation of CSR practices by analyzing their CSR reports. The study will not only provide practical implications for strengthening CSR practices in China's construction industry, but also serve as a reference for the research into CSR performance in other industries and other countries.

\section{Literature Review}

Social responsibility has been widely adopted as businesses are increasingly expected to respond to emerging social and environmental issue [26]. According to ISO26000, social responsibility refers to being responsible for the social and environmental impacts of the decisions and activities of organizations through transparency and ethical conduct $[27,28]$. Social responsibility has become a dominant topic, drawing increasing attention of academics and business leaders from all sectors [29]. Olanipekun et al. [30] have studied CSR practices between the construction sector and the manufacturing, mining, and banking sectors. Now, many studies have examined SR practices, implementation, performance, and benefits [31]. Khan et al. [32] have studied CSR practices in banking enterprises, Tourky et al. [33] have discussed the role of corporate identity in CSR implementation, and Li et al. [34] have developed CSR Performance Evaluation Model based on AHP-BP Neural Network. During the last decade, due to the negative impacts social media has brought to bear upon companies whose activities impact negatively on the biophysical environment and societies, the evolution of CSR literature and the increased requirement for CSR have moved the main research discussion from "whether or not" to "how" CSR can be implemented [31].

At present, CSR in the construction industry has received prevalent academic and industrial attention due to the tremendous influence exerted by construction activities on society and the environment $[35,36]$. The construction industry is a major consumer of natural resources $[37,38]$, consuming over 400 million tons of materials each year according to the United Kingdom Green Building Council [39]. Therefore, compared to other industries, more attention needs to be paid to the implementation of CSR in the construction industry in general [40]. CSR practices in the construction industry need to pay attention to the impact of the construction personnel behavior, construction work, and transaction activities on other stakeholders [11]. From the perspective of stakeholders, CSR is a management tool that can be used to coordinate stakeholder relationships and meet their expectations [41].

Although the social responsibility of construction enterprises is attracting increasing attention, current research is still in its infancy. Jiang and Wong [41] suggest that the study of social responsibility of construction enterprises mainly focuses on whether CSR is an imperative. It has been found that the implementation of CSR can enhance the competitiveness [13] and financial performance [24] of construction enterprises and endow them with a good image and reputation [20,42]. Considering the complicated and dynamic stakeholder environment in the construction industry, Lin et al. [43] suggested integrating stakeholder management and power theory into CSR research. From the perspective of the balance of stakeholders' power and responsibility, Lin et al. [44] developed a collaborative framework for implementing social responsibility issues in construction projects. One year later, Lin et al. [45] discussed the stakeholders' influence strategies on social responsibility implementation in construction projects.

There are subtle differences in CSR practices in different national conditions, political systems, or cultural backgrounds [46-49]. In analyzing the CSR reports of UK construction companies, for instance, Brown et al. [50] found that the CSR behavior of British contractors focuses mainly on staff health and safety, environment, energy resources, carbon dioxide, supply chains, and the community. Using a similar research method, Huang et al. [51] revealed that large- and medium-sized construction enterprises in 
Taiwan focus on environmental and ecological impacts and $\mathrm{CO}_{2}$ emissions during construction, while developers focus on environmental assessment and green building design prior to construction. Bevan and Yung [52] observed that Australian construction companies pay more attention to economic and moral responsibilities, at the expense of their environmental and community responsibilities. In Japan, based on the analysis of CSR reports during 2004-2012, Nagata et al. [53] found that the attention paid by the Japanese construction industry, manufacturing, transportation, and commercial enterprises to occupational health and development is increasing year by year. Through the analysis of 310 international contractor CSR reports released during 2009-2014, Liao et al. [21] found differences in the cognitive level of CSR and practices in Europe, Asia, United States/Canada, and China, with China ranked the lowest for both CSR communication awareness and practices.

To enable stakeholders to understand CSR implementation better, CSR reports are considered one of the main means of disclosure of CSR practice information and one of the most effective tools to convey CSR information to the outside world [54]. CSR reports enable stakeholders to better understand the CSR contribution of these enterprises and make correct enterprise evaluations. International construction enterprises are more likely to disclose CSR information in CSR reports mainly because they face more pressure from abroad and at home [55]. The cultural and institutional diversity of the international environment mean that they face more risks [56]. Thus, they are more likely to adopt CSR practices and publish CSR reports in order to reduce risk [57], create a good corporate image, and satisfy all stakeholders $[58,59]$.

Sustainability involves three main aspects including environmental, social, and economic sustainability [60]. According to ISO26000 and Macassa et al. [61], CSR requires enterprises to be responsible for the environmental, social, and economic impacts of their decisions and activities. In other words, CSR is an important part of sustainability, and CSR practices can improve sustainability performance $[62,63]$. At present, CSR reports have no unified standard of content. ISO26000 suggests that CSR should mainly include organizational governance, human rights, labor practice, environment, fair operation practice, consumer, community participation, and development, while SA8000 emphasizes labor rights. As the best-known framework for sustainability reporting by businesses worldwide, the Global Reporting Initiative (GRI) believes that CSR should involve the three dimensions of economy, environment, and society [64]. With the deepening of research into CSR, scholars find that it is not enough to focus on the specific content of CSR, but on how to achieve CSR goals through corporate governance. Today, corporate governance is included in many social responsibility standards, such as ISO26000, the RepuTex CSR index system, and China's Guidelines for the Compilation of CSR Reports. Corporate governance is a type of rule for allocating corporate resources and coordinating the relationships between stakeholders in an organization [65], which has a significant impact on the social performance of enterprises [66]. Good corporate governance can provide a platform for CSR implementation and information disclosure [19].

In China mainland, the establishment and distribution of CSR reports are semivoluntary, with no unified standard for construction CSR reporting. However, CSR disclosure, practices, and orientation from reports can be helpful in understanding how CSR is perceived and where further improvements can be made. Therefore, this paper is devoted to clarifying how Chinese construction enterprises understand and implement their CSR practices, and it provides suggestions for their development in the Chinese construction industry.

\section{Methodology}

Content analysis is a form of quantitative method that deconstructs text and transforms text that cannot be quantified into objective data that can be described and counted $[67,68]$. Content analysis is used in many studies to analyze reporting [69]. It is a systematic, replicable technique for compressing many words of text into fewer content categories based on explicit rules of coding [70, 71]. It provides a quantitative analysis of the content of literature and makes judgments and inferences based on quantitative data transformed from qualitative data. Therefore, it is used to obtain viewpoints and conclusions by counting the frequency of events or subjects described in CSR reports of Chinese construction enterprises.

In this study, the research process is divided into three steps: a preliminary analysis to determine the construction enterprises to research, then searching and obtaining their CSR reports, and finally analyzing them by content analysis.

The steps of the research method are summarized in Table 1. As to how each step is implemented in detail and what results are obtained, readers can refer to the graphical abstract in the supplementary material (available here). The graphical abstract describes the main research ideas of this paper, including research methods, research steps, and research results of each step.

3.1. Identifying the Research Objects. Considering that the preparation of CSR reports is not mandatory in China, normally only large- and medium-scale enterprises publish them-a fact confirmed by our preliminary research. To ensure that the CSR reports are reliable, the study involves the top 100 from the ranked list of 500 Chinese construction enterprises in 2016-a list evaluated by the Chinese Construction Enterprises Management Association and published in August each year. This is the most authoritative list of China's construction enterprises.

3.2. Searching and Obtaining the CSR Reports. In this study, CSR reports are used to reflect the CSR awareness and practices of Chinese construction enterprises. The CSR report provides an effective means for enterprises to communicate with the outside world and can partly reflect their contributions to fulfilling their social responsibilities. At the 
TABLE 1: Description of the research method.

\begin{tabular}{lc}
\hline Methodology steps & Main work \\
\hline $\begin{array}{l}\text { Step 1: identifying the research objects } \\
\text { Step 2: searching and obtaining the CSR } \\
\text { reports }\end{array}$ & Determining the top 100 from the ranked list of 500 Chinese construction enterprises in 2016 \\
Step 3: content analysis & Using a three-step data collection process to search and obtain the reports \\
\end{tabular}

same time, it is acknowledged that the richness, transparency, and even authenticity of the content of the reports need further verification $[72,73]$. Irrespective of this, however, the credibility of CSR reports has no intrinsic impact on the results of this paper as they still reflect the CSR awareness and practices of enterprises.

CSR reports were obtained from various sources in the public domain, including the enterprises' public websites, the websites of construction enterprise associations and stock exchange, and the general information network. In the process of searching the CSR reports, it is noted that they are often published as part of other reports, such as annual reports and sustainable development reports.

A three-step data collection process was adopted in collecting the CSR reports: firstly, determining whether an enterprise had issued an independent CSR report on the Internet, including the enterprises' public websites, the websites of construction enterprise associations and stock exchange, and the general information network; secondly, if not, finding sustainable development reports; finally, checking the annual report of the enterprise if there is no CSR information. If the three-step collection process did not identify any relevant CSR reporting, it was considered that the construction enterprise had not issued a CSR report. Moreover, as for the related reports, CSR information must appear as a separate chapter/section, and not just simply mentioned. In this way, 30 CSR reports (independent and integrated) were ultimately obtained from the 100 enterprises for detailed content analysis.

3.3. Content Analysis. As the best-known framework for sustainability reporting by businesses worldwide, the Global Reporting Initiative (GRI) believes that CSR should involve the three dimensions of economy, environment, and society [64]. With the deepening of research into CSR, scholars find that it is not enough to focus on the specific content of CSR, but on how to achieve CSR goals through corporate governance. Today, corporate governance is included in many social responsibility standards, such as China's Guidelines for the Compilation of CSR Reports. Corporate governance is a type of rule for allocating corporate resources and coordinating the relationships between stakeholders in an organization [65], which has a significant impact on the social performance of enterprises [66]. Good corporate governance can provide a platform for CSR implementation and information disclosure [19]. Therefore, referring to the GRI and Guidelines for the Compilation of CSR Reports for Chinese Construction Enterprises, the categories adopted before analysis comprised corporate governance (CG), economic responsibility (ER), environmental management (EM), and social practices (SP).

Each report of enterprises was read thoroughly, and all the initiatives mentioned were listed and grouped into one of these categories by manual statistics. One occurrence of the initiative under each category is counted as 1 ; otherwise, it is counted as 0 . If we found some initiatives not belonging to any of the categories in the process of practical analysis, those initiatives would be listed separately, and merged and encoded accordingly. Finally, five categories of frequency statistics were obtained. In order to ensure the correctness of the data, three researchers conducted several reviews and discussions after the frequency statistics were obtained. In this study, frequency refers to the total number of enterprises appearing in a category or secondary index.

The reliability of the CSR categories is tested by Cronbach's alpha. After determining the CSR categories, three experts were invited to provide statistics for five CSR reports according to the above five categories. Three groups of expert data were imported into SPSS 22, for calculating Cronbach's alpha. The results show that the average value of the Cronbach's alpha of the five categories is 0.82 . According to Neuendorf [74], a Cronbach's alpha of at least 0.8 is acceptable during content analysis.

In addition, the chi square contingency table test $\left(\chi^{2}\right)$ can explore some subtle and latent associations by determining the strength of relationship between two variables [75] and is used here to reveal the connections between different enterprise characteristics and CSR practices.

\section{Results and Analysis}

4.1. Profiles of Sample Enterprises. The basic characteristics of the 100 enterprises are summarized in Table 2.

Table 3 provides a breakdown of the type of information disclosure and the corporate nature of the enterprises, showing that, whether they are private/state-owned, international/noninternational, or stock listed/unlisted, all have a significant influence (at the 5\% level). This shows that $30 \%$ provide public CSR reports or other official reports where CSR information is used as a separate chapter/section (type A); $46 \%$ do not provide public CSR reports or other systematic information but do provide some CSR information on their official website (type B); and $24 \%$ do not provide any public CSR information (type C). The relatively small proportion of type A enterprises indicates that the majority of construction enterprises, even leading industry players, do not provide CSR reports.

State-owned, international, and stock listed enterprises are more likely to release CSR reports to the public than their 
TABLE 2: Descriptive statistics of the 100 enterprises.

\begin{tabular}{lcc}
\hline & Attribute & Count \\
\hline Nature & State-owned & 55 \\
& Private & 45 \\
Stock-listed enterprise & Listed & 37 \\
& Unlisted & 63 \\
Internationalization & International & 43 \\
& Noninternational & 57 \\
Size & Large (general assets $\geq 80$ million) & 100 \\
& Medium (50 million $\leq$ general assets $<80$ million) & 0 \\
\hline
\end{tabular}

Note. Internationalization means that the construction firms have business in other countries.

TABLE 3: Relationships between CSR information disclosure category and corporate nature.

\begin{tabular}{|c|c|c|c|c|c|c|}
\hline \multirow{2}{*}{ Attribute } & & \multicolumn{3}{|c|}{ Number of enterprises } & \multirow{2}{*}{ Total } & \multirow{2}{*}{$\chi^{2}$} \\
\hline & & $\mathrm{C}$ & $\mathrm{B}$ & A & & \\
\hline \multirow{4}{*}{ Nature } & & 10 & 26 & 8 & 44 & \multirow{4}{*}{$p=0.036^{*}$ d.f. $=2$} \\
\hline & Private & $22.7 \%$ & $59.1 \%$ & $18.2 \%$ & $100.0 \%$ & \\
\hline & \multirow{2}{*}{ State-owned } & 14 & 20 & 22 & 56 & \\
\hline & & $25.0 \%$ & $35.7 \%$ & $39.3 \%$ & $100.0 \%$ & \\
\hline \multirow{4}{*}{ Internationalization } & \multirow{2}{*}{ International } & 7 & 17 & 19 & 43 & \multirow{4}{*}{$p=0.022^{*}$ d.f. $=2$} \\
\hline & & $16.3 \%$ & $39.5 \%$ & $44.2 \%$ & $100.0 \%$ & \\
\hline & \multirow{2}{*}{ Noninternational } & 17 & 29 & 11 & 57 & \\
\hline & & $29.8 \%$ & $50.9 \%$ & $19.3 \%$ & $100.0 \%$ & \\
\hline \multirow{4}{*}{ Stock-listed enterprise } & \multirow{2}{*}{ Listed } & 1 & 12 & 24 & 37 & \multirow{4}{*}{$p \leq 0.001^{* *}$ d.f. $=2$} \\
\hline & & $2.7 \%$ & $32.4 \%$ & $64.9 \%$ & $100.0 \%$ & \\
\hline & \multirow{2}{*}{ Unlisted } & 23 & 34 & 6 & 63 & \\
\hline & & $36.5 \%$ & $54.0 \%$ & $9.5 \%$ & $100.0 \%$ & \\
\hline Total & - & 24 & 46 & 30 & 100 & \multirow{2}{*}{-} \\
\hline Iotal & - & $24.0 \%$ & $46.0 \%$ & $30.0 \%$ & $100.0 \%$ & \\
\hline
\end{tabular}

Note. Symbols ${ }^{* *}$ and ${ }^{*}$ denote $p \leq 0.01$ and $p \leq 0.05$, respectively.

counterparts are, with 22 of the 30 type A enterprises (providing CSR reports) being state-owned and 25 stock listed enterprises. This is likely due to CSR reporting being semimandatory in China. In 2012, the State-owned Assets Supervision and Administration Commission (SASAC) explicitly asked all central state-owned enterprises to issue CSR reports, while the Shanghai and Shenzhen stock exchanges also clarified the types of listed enterprises that should publish the reports. Although other enterprises are encouraged to take the initiative to issue reports, the majority do not publish reports mainly because the implementation of CSR and the presentation of a report will involve additional short-term costs [76], the reporting is voluntary and lacks legal enforcement [77], and public pressure is weak [78].

However, it is also important to note that the lack of CSR reporting does not necessarily mean that enterprises do not attach importance to CSR. As can be seen from Table 3, although only a small proportion of private, noninternational, and unlisted enterprises provide public CSR reports, the majority state their CSR commitment and practices on their websites.

4.2. Content Analysis of CSR Reports. Table 4 provides the results of the content analysis of the 30 CSR reports, identifying 36 specific CSR practices classified into five categories.

This indicates that the CSR practices mainly focus on internal corporate governance, environmental management, employee health and safety, economic responsibility, and community involvement. For the category of internal corporate governance, all 30 enterprises demonstrate that they are actively committed to ethics and values in corporate governance (1.1). The vast majority show they are doing business in accordance with the law (1.2) and constantly improving their governance structure (1.3). This is probably because good corporate governance builds stakeholder confidence in the enterprise's performance and minimizes employee turnover [79]. However, only $47 \%$ conduct information disclosure (1.8) and CSR planning (1.9), which indicates that CSR awareness is not a prominent feature of most construction enterprises in China. At present, their approach to managing CSR is mainly haphazard and responsive rather than of a strategic nature.

The category of environmental management focuses primarily on the construction process, covering energy conservation and emission reduction (2.1) and green construction (2.2). This is understandable, as construction activities have a variety of negative effects on the environment. However, construction enterprises also need to take responsibility for environmental restoration (2.6) and 
TABLE 4: CSR practices.

\begin{tabular}{|c|c|c|c|}
\hline Number & CSR practices & Frequency & Percent \\
\hline 1 & Corporate governance & & \\
\hline 1.1 & Ethical and moral values & 30 & 100 \\
\hline 1.2 & Abiding by the law & 27 & 90 \\
\hline 1.3 & Improving the governance structure & 25 & 83 \\
\hline 1.4 & Product strategy & 23 & 77 \\
\hline 1.5 & Anticorruption & 17 & 57 \\
\hline 1.6 & Stakeholder strategy & 17 & 57 \\
\hline 1.7 & Internal control supervision & 15 & 50 \\
\hline 1.8 & Information disclosure & 14 & 47 \\
\hline 1.9 & Planning of CSR & 14 & 47 \\
\hline 2 & Environmental management & & \\
\hline 2.1 & Energy conservation and emission reduction & 20 & 67 \\
\hline 2.2 & Green construction & 18 & 60 \\
\hline 2.3 & Construction noise dust treatment & 13 & 43 \\
\hline 2.4 & Environmental management system & 10 & 33 \\
\hline 2.5 & Construction waste disposal & 8 & 27 \\
\hline 2.6 & Vegetation and soil restoration & 7 & 23 \\
\hline 3 & Employee health and safety & & \\
\hline 3.1 & Staff training & 28 & 93 \\
\hline 3.2 & Production safety & 26 & 87 \\
\hline 3.3 & Worker health & 22 & 73 \\
\hline 3.4 & Social security welfare & 20 & 66 \\
\hline 3.5 & Caring for needy employees & 20 & 67 \\
\hline 3.6 & Equal employment & 19 & 63 \\
\hline 3.7 & Construction of cultural and recreational thought & 19 & 63 \\
\hline 3.8 & Caring for female employees & 14 & 46 \\
\hline 3.9 & Legal and open salary system & 13 & 43 \\
\hline 3.10 & Democratic rights & 13 & 43 \\
\hline 3.11 & Caring for migrant workers & 10 & 33 \\
\hline 3.12 & Employee performance evaluation & 10 & 33 \\
\hline 4 & Economic responsibility & & \\
\hline 4.1 & Creditor's rights protection & 12 & 40 \\
\hline 4.2 & Promoting economic development & 10 & 33 \\
\hline 4.3 & Continuous employment promotion & 9 & 30 \\
\hline 5 & Community engagement & & \\
\hline 5.1 & Against poverty & 26 & 87 \\
\hline 5.2 & Volunteer service & 24 & 80 \\
\hline 5.3 & Rescue and relief & 17 & 57 \\
\hline 5.4 & Recruiting and localizing employment & 15 & 50 \\
\hline 5.5 & Community resource compensation & 7 & 23 \\
\hline 5.6 & Overseas responsibility & 6 & 20 \\
\hline
\end{tabular}

implement environmental management systems (2.4) beyond the project construction stage, both of which were rarely covered in the CSR reports examined.

The category of employee health and safety reflects the enterprises' commitment to the development of employee productivity and community improvement through welfare support [20]. As construction activities are considered risky, with a high likelihood of occurrence of on-site accidents and injuries, most enterprises provide employee training (3.1) and pay close attention to worker safety (3.2) and health (3.3). Practices relating to employee remuneration (3.9) and performance evaluation (3.12) are less frequently mentioned. These initiatives relate to fairness, with more attention paid to needy employees (3.5) than female (3.8) and migrant employees (3.11). Whether this means that enterprises are paying insufficient attention or do not see the need to be mentioned in the CSR report is an issue to be resolved through future investigation.

The analysis of the category of economic responsibility shows that social and economic development should be established on the premise of the development of the enterprise itself. The research results indicate that Chinese construction enterprises are aware of the wide range of economic responsibilities involved in CSR reports. The enterprise's economic responsibility is not limited to the enterprise itself but extends to the national and social level. The sample enterprises have paid more attention to the rights of creditors $(4.1,40 \%)$ than the economic development $(4.2,33 \%)$ and the social stability of the country $(4.3,30 \%)$. The most likely reason is that economic development is considered the most basic responsibility of an enterprise and is usually covered in detail in annual reports, so there is little information in the CSR report. 
The CSR category of community engagement demonstrates that Chinese construction enterprises are attaching increasing importance to community public welfare. In particular, reporting the provision of voluntary services for the community (5.2) and poverty alleviation (5.1) is widely adopted (over $80 \%$ ). However, community resource compensation (5.5) and overseas responsibilities (5.6) are rarely mentioned (around 20\%). In particular, overseas responsibilities (5.6) are still in an early stage, with only six enterprises disclosing overseas liabilities. In general, reporting on overseas CSR is not a common practice, and international contractors focus only on simple poverty alleviation.

Of the initial 100 enterprises sampled, 44 and 56 are private and state-owned, respectively. However, of the 30 enterprises providing CSR reports, only 8 are private enterprises (18\% of the total 44 private firms) and the remaining 22 are state-owned (about 39\% of the total 56 state-owned firms). The reasons for the lack of CSR reports by private corporates are not necessarily that they do not pay attention to CSR practices, but are likely to be mainly due to cost considerations and/or lack of motivation for information disclosure. It is clear, however, that the motivation for publishing CSR reports in China is more attributable to external pressure, and there is not a great awareness in society of the need for information disclosure and communication.

As Table 5 shows, there are clear differences between state-owned and private enterprises. This is particularly the case with corporate governance and community engagement, to which state-owned enterprises pay much more attention than private enterprises. In contrast, private enterprises pay more attention to employee development and economic benefits.

As shown in Table 6, the notion that different dimensions of CSR practices are independent of the type of enterprise is rejected $(p \leq 0.001)$, meaning that there is a significant association between corporate nature and CSR practices. The main difference is that private enterprises pay more attention to economic issues and lack an awareness of community public welfare. In contrast, most state-owned enterprises do not mention economic responsibility but are prominent in focusing on community charity. Perhaps surprisingly, private enterprises pay more attention to their employees than state-owned enterprises do, which is probably because the private sector is under greater pressure to compete, and paying attention to the development of their employees is a good investment in labor resources, attracting and retaining capable employees, and further improving the enterprise's own strength [80].

\section{Discussion}

The results of this study indicate that international enterprises pay more attention to CSR than their noninternational counterparts and attach importance to such CSR activities as community development and participation. This is partly because international diversification, geographic diversification, etc. make CSR more complex [81]. With the internationalization of enterprises increasing, corporate
TABLE 5: Average number of CSR practices in each CSR category.

\begin{tabular}{lcccc}
\hline CSR category & \multicolumn{2}{c}{ Total frequency $^{\mathrm{a}}$} & \multicolumn{2}{c}{ Average $^{\mathrm{b}}$} \\
& $\begin{array}{c}\text { State- } \\
\text { owned }\end{array}$ & Private & $\begin{array}{c}\text { State- } \\
\text { owned }\end{array}$ & Private \\
\hline $\begin{array}{l}\text { Corporate governance } \\
\begin{array}{l}\text { Environmental } \\
\text { management }\end{array}\end{array}$ & 143 & 39 & 6.50 & 4.88 \\
$\begin{array}{l}\text { Employee health and } \\
\text { safety }\end{array}$ & 143 & 71 & 6.32 & 3.13 \\
$\begin{array}{l}\text { Economic responsibility } \\
\begin{array}{l}\text { Community } \\
\text { engagement }\end{array}\end{array}$ & 18 & 13 & 0.82 & 1.63 \\
\hline
\end{tabular}

Note. There are 22 state-owned enterprises and 8 private enterprises; ${ }^{a}$ the total frequency of all initiatives in each category in Table $2 ;^{b}$ the average score of each enterprise under each category (total frequency/number of enterprises).

social performance is also expected to increase [82], with the emphasis of CSR practices being different for different cultures and institutions. In transnational cooperation, for instance, tailor-made CSR strategies can help shorten the cultural/institutional distance between home and host countries [10]. It is also necessary to coordinate relationships with local communities; otherwise, unless the potential negative impacts are dealt with appropriately, social tensions or group incidents can arise, with their concomitant effects on projects and society as a whole $[83,84]$. This is the reason why international contractors attach importance to such CSR activities as community development and participation [21].

In addition, international enterprises are more likely to publish CSR reports in order to increase their competitive advantage and reduce operational risks. According to $\mathrm{He}$ et al. [85], culture of Chinese construction industry was dominated by outcome-oriented, collectivism, and high uncertainty avoidance. When Chinese construction enterprises are faced with international diversification and geographic diversification [81], they are more inclined to issue CSR reports to reduce the high uncertainty in the construction process. In addition, $\mathrm{Ma}$ et al. [82] also point out the positive linkage between internationalization and CSR reports. International enterprises have a greater awareness of the benefits of publishing reports than purely domestic enterprises do.

According to the content analysis results, many construction enterprises have not incorporated CSR into the corporate governance system in China. Only $47 \%$ of the top 100 construction enterprises conducted information disclosure and CSR planning in corporate governance. Good corporate governance can significantly influence the social performance of companies according to Ma et al. [82]. This aspect of organizational governance for fulfilling CSR can ensure that top management are committed to, and take responsibility for, CSR and create fair opportunities for underrepresented groups [21]. Therefore, according to Knox and Maklan [86], one of the obstacles to the development of Chinese contractors' CSR is the lack of a systematic framework linking investment in these responsibilities to social or business outcomes. 
TABLE 6: Relationship between the type of enterprise and CSR dimensions.

\begin{tabular}{|c|c|c|c|c|c|c|c|}
\hline \multirow{2}{*}{\multicolumn{2}{|c|}{ Type of enterprises }} & \multicolumn{5}{|c|}{ CSR dimensions } & \multirow[b]{2}{*}{ Total } \\
\hline & & $\begin{array}{l}\text { Corporate } \\
\text { governance }\end{array}$ & $\begin{array}{c}\text { Environmental } \\
\text { management }\end{array}$ & $\begin{array}{l}\text { Employee health } \\
\text { and safety }\end{array}$ & $\begin{array}{l}\text { Economic } \\
\text { responsibility }\end{array}$ & $\begin{array}{l}\text { Community public } \\
\text { involvement }\end{array}$ & \\
\hline \multirow{2}{*}{$\begin{array}{l}\text { State- } \\
\text { owned }\end{array}$} & Count & 155 & 51 & 143 & 19 & 83 & 451 \\
\hline & Percent & $34.4 \%$ & $11.3 \%$ & $31.7 \%$ & $4.2 \%$ & $18.4 \%$ & $100 \%$ \\
\hline \multirow{2}{*}{ Private } & Count & 44 & 25 & 71 & 19 & 12 & 171 \\
\hline & Percent & $25.7 \%$ & $14.6 \%$ & $41.5 \%$ & $11.1 \%$ & $7.0 \%$ & $100 \%$ \\
\hline \multirow{2}{*}{ Total } & Count & 199 & 76 & 214 & 38 & 95 & 622 \\
\hline & Percent & $32.0 \%$ & $12.2 \%$ & $34.4 \%$ & $6.1 \%$ & $15.3 \%$ & $100 \%$ \\
\hline
\end{tabular}

Note. $\chi^{2}=27.656(p \leq 0.001$, d. $f .=4)$.

The trend of information disclosure is that enterprises pay more attention to external pressure or the impact on their corporate image, and environmental information disclosure is still lacking. The results reveal that energy saving and emission reduction (2.1) and green construction (2.2) have received much attention (over 60\%), which is partly due to the Chinese government's requirements for environmental protection in recent years and the promulgation of a series of related standards and norms. The other two even more popular reported practices are against poverty (5.1) and volunteer service (5.2) (more than $80 \%$ ), which have a clear direct role in improving the image of enterprises. The overall trend of information disclosure is that enterprises pay more attention to external pressure or the impact on their corporate image, which is consistent with the perspectives of Cho and Patten [87] and Yongvanich and Guthrie [88]. Clearly, considering the nature of construction production activities, it is every contractor's obligation to preserve the environment $[89,90]$, and Chinese contractors should attach great importance to environmental protection [23]. On the other hand, it is surprising that the lack of information disclosure up to 2014 found by Liao et al. [21] continues today. Moreover, the Chinese contractors' lack of a systematic approach to environmental management, with more attention being paid to such negative environmental factors as noise, dust, energy conservation, and emission reduction [21], is also an enduring theme.

The content analysis also reveals that construction enterprises' awareness of public welfare is quite low. They mainly concentrate on charitable donations (5.1 and 5.2) and ignore communication with the community (5.4 and 5.5). Lazarevic [89] accuses enterprises of paying close attention to the stakeholders with direct interests in the enterprise, while ignoring such indirect stakeholders as the community, which would hinder the development of the enterprise's CSR. Li et al. [91] also point out that public participation in construction projects is less prevalent in eastern (e.g., China) than western societies.

The findings of this study indicate that Chinese construction enterprises attach great importance to the rights and interests of migrant workers (3.11), which is related to the production features and policy practice of Chinese construction industry. Due to the existence of Chinese demographic dividend, migrant workers have made great contributions to the development of Chinese construction industry in the past few decades. According to Ke [92], 75\% of workers in the construction industry are migrant workers.
In recent years, the State Council of China has issued many policies to protect the rights of migrant workers, such as several opinions of the State Council of China on solving the problem of migrant workers, opinions of the State Council of China on further serving migrant workers, and the State Council of China comprehensive opinions on governing the problem of arrears of peasant workers' wages. The importance of migrant workers in Chinese construction industry and the government's attention have made companies pay more attention to the rights and interests of migrant workers. In addition, construction activities are characterized by high-intensity and high-risk activities, occupational health and safety (OHS) is important for construction enterprises in all countries. The production features of construction activities require companies to pay more attention to the rights and interests of construction workers.

\section{Conclusion and Future Research}

6.1. Conclusion. In order to clarify how Chinese construction enterprises understand and implement their CSR practices, this research analyzes and studies the CSR disclosure and CSR practices of 100 of the country's construction enterprises. The following conclusions are drawn:

(1) The awareness of construction CSR practices needs to be improved in the future in China. The findings reveal that CSR information disclosure is not widely adopted, as only $30 \%$ of enterprises provide public CSR reports. In particular, only 8 of the 30 enterprises (providing public CSR reports) are private corporates (around 37\%). It is suggested that the government and industry need to further prompt Chinese construction enterprises to carry out CSR practices actively.

(2) Generally, Chinese construction enterprises' current CSR behavior is passively responsive without a sound management system, and enterprises pay more attention to short-term measures that have a greater impact on the enterprise's image. While the contractors generally pay great attention to internal corporate governance, they do not include social responsibility at the organizational management level. The enterprises focus on environmental management in the construction process but not in the postcompletion phase. In addition, the 
enterprises awareness and contribution to community involvement are still at a very early stage compared to their international counterparts.

(3) State-owned and private enterprises have different perceptions of CSR and CSR practices. Private enterprises pay more attention to economic benefits than community welfare, while most state-owned enterprises are obliged to contribute to public welfare because of state regulations.

(4) CSR reports can provide a good channel to convey the implementation of CSR. However, our research found that only $19.3 \%$ of domestic noninternational enterprises have issued CSR reports. Moreover, while the internationalization of enterprises is the current trend of economic globalization, only $47 \%$ of the top 100 construction enterprises conducted information disclosure and CSR planning in corporate governance. Meanwhile, however, in the context of different political and cultural backgrounds in different countries, the implementation of CSR has attracted much attention. Facing a background of economic globalization, therefore, enterprises working in other countries need to pay attention to the release of their CSR reports and integrate CSR into their corporate governance system.

6.2. Limitations and Future Research. This paper has certain theoretical and practical significance. Previous research into the CSR awareness and practices of Chinese construction enterprises mainly focuses on large international contractors, while this study investigates the CSR practices of domestic enterprises, which expands the research scope of CSR practices in construction industry. In addition, researching CSR practices of construction enterprises by analyzing CSR reports is a new approach, which provides a new perspective for the study of CSR theory. In practice, the results of this research paper can be used to guide construction enterprises to the improved disclosure of CSR information and the intensity of CSR practices.

However, while we understand the CSR practices of construction enterprises in 2016 through the analysis of CSR reports, the dynamic evolution of CSR practices from 2016 to 2020 is unknown and is clearly a topic for future research.

\section{Data Availability}

All data generated or used during the study are available from the corresponding author upon request.

\section{Conflicts of Interest}

The authors declare that there are no conflicts of interest in connection with the work submitted.

\section{Acknowledgments}

The authors gratefully acknowledge the funding and support provided by the National Natural Science Foundation of China (NSFC) (Grant nos. 71871096 and 71871164).

\section{Supplementary Materials}

Graphical Abstract. This supplementary material describes the main research ideas of this paper, including research methods, research steps, and research results of each step. Readers can quickly get the main research content of the paper through the graphical abstract. (Supplementary Materials)

\section{References}

[1] W. Li, W. Wang, H. Gao et al., "Evaluation of regional metafrontier total factor carbon emission performance in China's construction industry: analysis based on modified non-radial directional distance function," Journal of Cleaner Production, vol. 256, Article ID 120425, 2020.

[2] L. S. Pheng and H. Jiang, "Internationalization of Chinese construction enterprises," Journal of Construction Engineering \& Management, vol. 129, no. 6, pp. 589-598, 2003.

[3] R. Y. Sunindijo and P. X. W. Zou, "Political skill for developing construction safety climate," Journal of Construction Engineering and Management, vol. 138, no. 5, pp. 605-612, 2012.

[4] National Bureau of Statistics of China, Statistical Communique of the People's Republic of China on the 2017 National Economic and Social Development, National Bureau of Statistics of China, Beijing, China, 2018, http://www.stats. gov.cn/english/PressRelease/201802/t20180228_1585666. html.

[5] B. Li, S. Han, Y. Wang, J. Li, and Y. Wang, "Feasibility assessment of the carbon emissions peak in China's construction industry: factor decomposition and peak forecast," Science of The Total Environment, vol. 706, Article ID 135716, 2019.

[6] Y. Wu, K. W. Chau, W. Lu, L. Shen, C. Shuai, and J. Chen, "Decoupling relationship between economic output and carbon emission in the Chinese construction industry," Environmental Impact Assessment Review, vol. 71, pp. 60-69, 2018.

[7] T. Huo, M. Tang, W. Cai, H. Ren, B. Liu, and X. Hu, "Provincial total-factor energy efficiency considering floor space under construction: an empirical analysis of China's construction industry," Journal of Cleaner Production, vol. 244, Article ID 118749, 2020.

[8] S. Barthorpe, "Implementing corporate social responsibility in the UK construction industry," Property Management, vol. 28, no. 1, pp. 4-17, 2010.

[9] Q. Zhang, B. L. Oo, and B. T. H. Lim, "Drivers, motivations, and barriers to the implementation of corporate social responsibility practices by construction enterprises: a review," Journal of Cleaner Production, vol. 210, pp. 563-584, 2019.

[10] W. Lu, M. Ye, R. Flanagan, and K. Ye, "Corporate social responsibility disclosures in international construction business: trends and prospects," Journal of Construction Engineering and Management, vol. 142, no. 1, 2016.

[11] J.-P. Gond, N. Kang, and J. Moon, "The government of selfregulation: on the comparative dynamics of corporate social responsibility," Economy and Society, vol. 40, no. 4, pp. 640-671, 2011.

[12] M. Murray and A. Dainty, Corporate Social Responsibility in the Construction Industry, Taylor \& Francis, London, UK, 2013. 
[13] J. J. Asongu, "Innovation as an argument for corporate social responsibility," Journal of Business \& Public Policy, vol. 1, no. 3, pp. 1-21, 2007.

[14] Y. Tan, L. Shen, and H. Yao, "Sustainable construction practice and contractors' competitiveness: a preliminary study," Habitat International, vol. 35, no. 2, pp. 225-230, 2011.

[15] M. E. Porter and M. R. Kramer, "Strategy and society: the link between competitive advantage and corporate social responsibility," Harvard Business Review, vol. 84, no. 12, pp. 78-92, 2006.

[16] S. Brammer and S. Pavelin, "Voluntary social and environmental disclosures by large UK companies," Business Ethics A European Review, vol. 13, no. 2, 2004.

[17] J. Glass, "The state of sustainability reporting in the construction sector," Smart and Sustainable Built Environment, vol. 1, no. 1, pp. 87-104, 2012.

[18] A. Jose and S.-M. Lee, "Environmental reporting of global corporations: a content analysis based on website disclosures," Journal of Business Ethics, vol. 72, no. 4, pp. 307-321, 2007.

[19] S. Petrovic-Lazarevic, "Good corporate citizenship in the Australian construction industry," Corporate Governance, vol. 10, no. 2, pp. 115-128, 2010.

[20] Z.-Y. Zhao, X.-J. Zhao, K. Davidson, and J. Zuo, "A corporate social responsibility indicator system for construction enterprises," Journal of Cleaner Production, vol. 29-30, pp. 277-289, 2012.

[21] P.-C. Liao, N.-N. Xia, C.-L. Wu, X.-L. Zhang, and J.-L. Yeh, "Communicating the corporate social responsibility (CSR) of international contractors: content analysis of CSR reporting," Journal of Cleaner Production, vol. 156, pp. 327-336, 2017.

[22] L. Tang and H. Li, "Corporate social responsibility communication of Chinese and global corporations in China," Public Relations Review, vol. 35, no. 3, pp. 199-212, 2009.

[23] W. Jiang and J. K. W. Wong, "Key activity areas of corporate social responsibility (CSR) in the construction industry: a study of China," Journal of Cleaner Production, vol. 113, pp. 850-860, 2016.

[24] B. Xiong, W. Lu, M. Skitmore, K. W. Chau, and M. Ye, "Virtuous nexus between corporate social performance and financial performance: a study of construction enterprises in China," Journal of Cleaner Production, vol. 129, pp. 223-233, 2016.

[25] Chinese Construction Enterprises Management Association, The List of Top 500 Chinese Construction Enterprises Management Association, Chinese Construction Enterprises Management Association, Guangzhou, China, 2017, http:// www.ccema.com.cn/zt/jianzhu2017.html.

[26] F. Schultz, I. Castelló, and M. Morsing, "The construction of corporate social responsibility in network societies: a communication view," Journal of Business Ethics, vol. 115, no. 4, pp. 681-692, 2013.

[27] M. Ferrara, M. Khademi, M. Salimi, S. Sharifi, and F. Cacace, "A dynamic Stackelberg game of supply chain for a corporate social responsibility," Discrete Dynamics in Nature and Society, vol. 2017, Article ID 8656174, 8 pages, 2017.

[28] M. Ye, W. Lu, R. Flanagan, and K. W. Chau, "Corporate social responsibility "glocalisation": evidence from the international construction business," Corporate Social Responsibility and Environmental Management, vol. 27, no. 1, 2019.

[29] M. Vilanova, J. M. Lozano, and D. Arenas, "Exploring the nature of the relationship between CSR and competitiveness," Journal of Business Ethics, vol. 87, no. 1, pp. 57-69, 2009.
[30] A. O. Olanipekun, O. S. Oshodi, A. Darko, and T. Omotayo, "The state of corporate social responsibility practice in the construction sector," Smart and Sustainable Built Environment, vol. 9, no. 2, pp. 91-111, 2019.

[31] A. Alotaibi, F. Edum-Fotwe, and A. D. F. Price, "Critical barriers to social responsibility implementation within megaconstruction projects: the case of the Kingdom of Saudi Arabia," Sustainability, vol. 11, no. 6, p. 1755, 2019.

[32] H. Z. Khan, S. Bose, and R. Johns, "Regulatory influences on csr practices within banks in an emerging economy: do banks merely comply?" Critical Perspectives on Accounting, vol. 71, Article ID 102, 2020.

[33] M. Tourky, P. Kitchen, and A. Shaalan, "The role of corporate identity in CSR implementation: an integrative framework," Journal of Business Research, vol. 117, pp. 694-706, 2020.

[34] W. Li, G. Xu, Q. Xing, and M. Lyu, “Application of improved AHP-BP neural network in CSR performance evaluation model," Wireless Personal Communications, vol. 111, no. 4, pp. 2215-2230, 2020.

[35] X. Lin, C. M. F. Ho, and G. Q. P. Shen, "Who should take the responsibility? Stakeholders' power over social responsibility issues in construction projects," Journal of Cleaner Production, vol. 154, pp. 318-329, 2017.

[36] M. Loosemore and B. T. H. Lim, "Linking corporate social responsibility and organizational performance in the construction industry," Construction Management \& Economics, vol. 35, no. 3, pp. 90-105, 2017.

[37] T. A. Kumar, P. Asokan, and T. V. Kumar, "Resource efficiency impact on marble waste recycling towards sustainable green construction materials," Current Opinion in Green \& Sustainable Chemistry, vol. 13, pp. 91-101, 2018.

[38] T. Vilutiene, M. R. Hosseini, E. Pellicer, and E. K. Zavadskas, "Advanced BIM applications in the construction industry," Advances in Civil Engineering, vol. 2019, Article ID 6356107, 3 pages, 2019.

[39] M. Shan, W. Liu, B. Hwang, and J. Lye, "Critical success factors for small contractors to conduct green building construction projects in Singapore: identification and comparison with large contractors," Environmental Science and Pollution Research, vol. 27, pp. 8310-8322, 2020.

[40] X. Li, X. Gao-Zeller, T. E. Rizzuto, and F. Yang, "Institutional pressures on corporate social responsibility strategy in construction corporations: the role of internal motivations," Corporate Social Responsibility and Environmental Management, vol. 26, no. 4, pp. 721-740, 2019.

[41] W. Jiang and J. K. W. Wong, "Corporate social responsibility in construction: a critical review on research," in Proceedings of the 19th International Symposium on Advancement of Construction Management and Real Estate, Chongqing, China, 2015.

[42] C.-F. Huang and H.-C. Lien, "An empirical analysis of the influences of corporate social responsibility on organizational performance of Taiwan's construction industry: using corporate image as a mediator," Construction Management and Economics, vol. 30, no. 4, pp. 263-275, 2012.

[43] X. Lin, C. M. F. Ho, and G. Q. P. Shen, "Research on corporate social responsibility in the construction context: a critical review and future directions," International Journal of Construction Management, vol. 18, no. 5, pp. 394-404, 2017.

[44] X. Lin, C. M.-F. Ho, and G. Q. Shen, "For the balance of stakeholders' power and responsibility," Management Decision, vol. 56, no. 3, pp. 550-569, 2018.

[45] X. Lin, B. McKenna, C. M. F. Ho, and G. Q. P. Shen, "Stakeholders' influence strategies on social responsibility 
implementation in construction projects," Journal of Cleaner Production, vol. 235, pp. 348-358, 2019.

[46] J. H. Bae and R. Salomon, "Institutional distance in international business research," in The Past, Present and Future of International Business \& Management, pp. 327-349, Emerald Group Publishing Limited, Bingley, UK, 2010.

[47] A. B. Novakovskiy, S. P. Maslova, I. V. Dalke, Y. A. Dubrovskiy, and R. C. Sihag, "Patterns of allocation CSR plant functional types in northern Europe," International Journal of Ecology, vol. 2016, Article ID 1323614, 11 pages, 2016.

[48] W. Tijhuis and R. Fellows, Culture in International Construction, Spon Press, London, UK, 2011.

[49] J. Tu, P. Chiu, Y. Huang, C. Hsu, and T. Meen, "Influential factors and strategy of sustainable product development under corporate social responsibility in Taiwan," Mathematical Problems in Engineering, vol. 2013, Article ID 303850, 15 pages, 2013.

[50] J. Brown, T. Parry, and J. Moon, "Corporate responsibility reporting in UK construction," Proceedings of the Institution of Civil Engineers-Engineering Sustainability, vol. 162, no. 4, pp. 193-205, 2009.

[51] C. F. Huang, W. H. Lu, T. T. Lin, and E. J. Wu, "The current conditions of CSR implementation in construction industry: a lesson from Taiwan," Applied Ecology and Environmental Research, vol. 15, pp. 67-80, 2017.

[52] E. A. M. Bevan and P. Yung, "Implementation of corporate social responsibility in Australian construction SMEs," Engineering, Construction and Architectural Management, vol. 22, no. 3, pp. 295-311, 2015.

[53] T. Nagata, A. Nakata, K. Mori, T. Maruyama, F. Kawashita, and M. Nagata, "Occupational safety and health aspects of corporate social responsibility reporting in Japan from 2004 to 2012," BMC Public Health, vol. 17, p. 381, 2017.

[54] I. Lock and P. Seele, "Analyzing sector-specific CSR reporting: social and environmental disclosure to investors in the chemicals and banking and insurance industry," Corporate Social Responsibility and Environmental Management, vol. 22, no. 2, pp. 113-128, 2013.

[55] R. V. Aguilera and G. Jackson, "The cross-national diversity of corporate governance: dimensions and determinants," Academy of Management Review, vol. 28, pp. 447-465, 2003.

[56] M. W. Peng, "The global strategy of emerging multinationals from China," Global Strategy Journal, vol. 2, no. 2, pp. 97-107, 2012.

[57] X. Yang and C. Rivers, "Antecedents of CSR practices in MNCs' subsidiaries: a stakeholder and institutional perspective," Journal of Business Ethics, vol. 86, no. 2, pp. 155-169, 2009.

[58] H. Lin, S. Zeng, H. Ma, and H. Chen, "Does commitment to environmental self-regulation matter? An empirical examination from China," Management Decision, vol. 53, no. 5, pp. 932-956, 2015.

[59] D. J. Wood, "Measuring corporate social performance: a review," International Journal of Management Reviews, vol. 12, no. 1, pp. 50-84, 2010.

[60] Y. Song, H. Wang, and M. Zhu, "Sustainable strategy for corporate governance based on the sentiment analysis of financial reports with CSR," Financial Innovation, vol. 4, no. 1, pp. 1-14, 2018.

[61] G. Macassa, C. Mcgrath, G. Tomaselli, and S. C. Buttigieg, "Corporate social responsibility and internal stakeholders' health and well-being in Europe: a systematic descriptive review," Health Promotion International, 2020.
[62] J. Abbas, "Impact of total quality management on corporate green performance through the mediating role of corporate social responsibility," Journal of Cleaner Production, vol. 242, Article ID 118458, 2020.

[63] M. Shahzad, Y. Qu, S. A. Javed, A. U. Zafar, and S. U. Rehman, "Relation of environment sustainability to CSR and green innovation: a case of Pakistani manufacturing industry," Journal of Cleaner Production, vol. 253, Article ID 1, 2019.

[64] H. S. Brown, M. de Jong, and T. Lessidrenska, "The rise of the global reporting initiative: a case of institutional entrepreneurship," Environmental Politics, vol. 18, no. 2, 2009.

[65] C. M. Daily, D. R. Dalton, and A. A. Cannella, "Corporate governance: decades of dialogue and data," Academy of Management Review, vol. 28, no. 3, pp. 371-382, 2003.

[66] H. Jo and M. A. Harjoto, "The causal effect of corporate governance on corporate social responsibility," Journal of Business Ethics, vol. 106, no. 1, pp. 53-72, 2012.

[67] C. Liang, C. Xu, H. Lu, and J. Han, "Personalized sports video customization using content and context analysis," International Journal of Digital Multimedia Broadcasting, vol. 2010, Article ID 836357, 20 pages, 2010.

[68] X. Ping, Research on Incentive Policies of Scientific and Technological Achievement Transformation Based on Content Analysis, Huazhong University of Science and Technology, Wuhan, China, 2019.

[69] L. C. Roca and C. Searcy, "An analysis of indicators disclosed in corporate sustainability reports," Journal of Cleaner Production, vol. 20, no. 1, pp. 103-118, 2012.

[70] K. H. Krippendorff, Content Analysis: An Introduction to Its Methodology, Vol. 79, Sage Publications, Thousand Oaks, CA, USA, 4th edition, 2018.

[71] S. Stemler, "An overview of content analysis in practical assessment," Practical Assessment, Research, and Evaluation, vol. 7, no. 17, 2001.

[72] N. Dando and T. Swift, "Transparency and assurance minding the credibility gap," Journal of Business Ethics, vol. 44, no. 2, pp. 195-200, 2003.

[73] M. J. Milne and R. Gray, "W(h)ither ecology? The triple bottom line, the global reporting initiative, and corporate sustainability reporting," Journal of Business Ethics, vol. 118, no. 1, pp. 13-29, 2013.

[74] K. A. Neuendorf, The Content Analysis Guidebook, Sage Publications, Thousand Oaks, CA, USA, 2016.

[75] D. R. Anderson, D. J. Sweeney, T. A. Williams, J. Freeman, and E. Shoesmith, Statistics for Business and Economics, Vol. 60, Cengage, Boston, MA, USA, 2nd edition, 2010.

[76] A. R. Belal and D. L. Owen, "The views of corporate managers on the current state of, and future prospects for, social reporting in Bangladesh," Accounting Auditing \& Accountability Journal, vol. 20, pp. 472-494, 2013.

[77] C. J. D. Villiers, "Why do South African companies not report more environmental information when managers are so positive about this kind of reporting?" Meditari Accountancy Research, vol. 11, pp. 11-23, 2013.

[78] W. Ali, J. G. Frynas, and Z. Mahmood, "Determinants of corporate social responsibility (CSR) disclosure in developed and developing countries: a literature review," Corporate Social Responsibility \& Environmental Management, vol. 24, no. 4, pp. 273-294, 2017.

[79] N. A. M. Ghazali, "Ownership structure and corporate social responsibility disclosure: some Malaysian evidence," Corporate Governance International Journal of Business in Society, vol. 7, no. 3, pp. 251-266, 2013. 
[80] F. Ciliberti, P. Pontrandolfo, and B. Scozzi, "Logistics social responsibility: standard adoption and practices in Italian companies," International Journal of Production Economics, vol. 113, no. 1, pp. 88-106, 2008.

[81] J. Kang, "The relationship between corporate diversification and corporate social performance," Strategic Management Journal, vol. 34, no. 1, pp. 94-109, 2012.

[82] H. Ma, S. Zeng, G. Q. Shen, H. Lin, and H. Chen, "International diversification and corporate social responsibility," Management Decision, vol. 54, no. 3, pp. 750-774, 2016.

[83] J. Liu, X. Zhao, and P. Yan, "Risk paths in international construction projects: case study from Chinese contractors," Journal of Construction Engineering \& Management, vol. 142, no. 6, Article ID 05016002, 2016.

[84] Z.-Z. Liu, Z.-W. Zhu, H.-J. Wang, and J. Huang, "Handling social risks in government-driven mega project: an empirical case study from west China," International Journal of Project Management, vol. 34, no. 2, pp. 202-218, 2016.

[85] Q. He, J. Li, J. Wan, Z. Zhang, and Z. Chen, "The passing fads and emergent trends of project culture in construction industry," Advances in Civil Engineering, vol. 2020, Article ID 9581901, 12 pages, 2020.

[86] S. Knox and S. Maklan, "Corporate social responsibility: moving beyond investment towards measuring outcomes," European Management Journal, vol. 22, no. 5, pp. 508-516, 2004.

[87] C. H. Cho and D. M. Patten, "The role of environmental disclosures as tools of legitimacy: a research note," Accounting, Organizations and Society, vol. 32, no. 7-8, pp. 639-647, 2007.

[88] K. Yongvanich and J. Guthrie, "Extended performance reporting: an examination of the Australian mining industry," Accounting Forum, vol. 29, no. 1, pp. 103-119, 2005.

[89] S. P. Lazarevic, "The development of corporate social responsibility in the Australian construction industry," Construction Management \& Economics, vol. 26, no. 2, pp. 93-101, 2008.

[90] L.-Y. Shen, V. W. Y. Tam, L. Tam, and Y.-B. Ji, "Project feasibility study: the key to successful implementation of sustainable and socially responsible construction management practice," Journal of Cleaner Production, vol. 18, no. 3 , pp. 254-259, 2010.

[91] T. H. Y. Li, S. T. Ng, and M. Skitmore, "Conflict or consensus: an investigation of stakeholder concerns during the participation process of major infrastructure and construction projects in Hong Kong," Habitat International, vol. 36, no. 2, pp. 333-342, 2012.

[92] Y. Ke, "Research on the Chinese industrialized construction migrant workers from the perspective of complex adaptive system: combining the application of SWARM computer simulation technology," Wireless Personal Communications, vol. 102, no. 4, pp. 2469-2481, 2018. 